\title{
EQUAL ACCESS TO PRIMARY EDUCATION IN ENVIRONMENTALLY CHALLENGED AREA OF BANGLADESH: A STUDY INTO THE TANGUAR HAOR OF SUNAMGANJ DISTRICT
}

\author{
Maruf Mia ${ }^{1}$
}

\begin{abstract}
The Tanguar Haor is overwhelmed with huge problems such as flash floods, poverty, extreme dependency on natural resources, lack of alternative sources of income, inadequate health facilities and sanitary latrines, scarcity of potable water, poor road connectivity, the insufficient and flimsy infrastructure of educational institutions. The main objective of this research is to find out the core causes of these problems and to examine how these problems make hindrances to ensure equal access to primary education in Tanguar Haor. Simultaneously, this study has analysed the existing scenario of primary education in this area. Both qualitative and quantitative approaches have been incorporated in this fieldwork-based study. The survey, FGD, and KII methods have been applied in this research to collect primary data from sixty (60) respondents of purposively selected villages and primary schools. The researcher has identified major drawbacks such as poverty, dropout, high repetition, absenteeism in school, shortage of enough teachers that create serious obstacles towards ensuring equal access to primary education in the Tanguar Haor of Sunamganj District. Finally, this study concludes that climate change-induced threats and environmental vulnerabilities are mainly responsible for producing these snags.
\end{abstract}

Keywords: Flash Flood, Poverty, Migration, Dropout, Repetition

\section{Introduction}

Haors with their unique hydro-ecological features are large bowl-shaped floodplain depressions located in the North-Eastern region of Bangladesh

\footnotetext{
1 Maruf Mia is an Assistant Professor (Political Science), School of Social Sciences, Humanities and Languages, Bangladesh Open University, Gazipur-1705, Bangladesh. Email: smmaruf84@gmail.com
}

Social Science Review [The Dhaka University Studies, Part-D], Vol. 38, No. 1, June 2021 DOI: https://doi.org/10.3329/ssr.v38i1.56530 
covering 1.99 million ha (hectare) of the area and accommodating about 19.37 million people (Centre for Environmental and Geographic Information Services [CEGIS], 2012b). There are almost 373 haors located in the districts of Sunamganj, Habiganj, Netrokona, Kishoreganj, Sylhet, Moulvibazar, and Brahmanbaria. These 373 haors cover 858,000 ha area that is around $43 \%$ of the total area of the Haor region (CEGIS, 2012b). Among the haor area of these seven districts, Sunamganj has the largest haor area of 268,531 ha which is about $73 \%$ of the total area of the district (CEGIS, 2012b).

The Haor region has long been lagging the mainstream of national development, and at the same time, it is lagging in education. The forthcoming challenges regarding climate change and variability are also a major concern for the sustainable development of the region. Bangladesh is considered as one of the most vulnerable countries in the world due to climate change and the impact of climate change perhaps even worse than that anticipated (Ministry of Environment and Forests [MoEF], 2009). Environmental hazards seriously affect the primary education of the Haor area. The literacy rate of the population of haor districts is on an average of $38 \%$. Among the haor districts, Moulvibazar has the highest literate population (42\%) whereas Sunamganj has the lowest percentage (33\%) of literate people (CEGIS, 2012a). The highest rate of attendance in primary and secondary school is noticed in Moulvibazar at $81 \%$ and the lowest in Sunamganj at $67 \%$ (CEGIS, 2012a). The dropout of primary students is very high in the haor region at $44 \%$ due to their poor socio-economic condition (CEGIS, 2012a). The transition of students from primary school to secondary school in haor area is low (60\%) (CEGIS, 2012a). In this connection, it has become imperative to do in-depth research on 'primary education' that is one of the fundamental drawbacks behind the development of the Haor area.

This study has been conducted in the Tanguar Haor of Sunamganj District under Sylhet Division. This hoar consists of two Upazilas - Tahirpur and Dharmapasha. Tahirpur Upazila covers the maximum area of Tanguar Haor. Tanguar Haor covers four unions-Uttar Sreepur, Dakshin Sreepur (Tahirpur), Uttar Bangshikunda, and Dakshin Bangshikunda (Dharmapasha). Data have been collected from purposively selected primary schools and villages of these four unions which are severely affected by environmental hazards. The impact of environmental threats on primary education has been analysed in terms of enrolment, retention, quality, and more importantly dropout in line with the 
research question of this study - 'how do environmental vulnerabilities make hindrances to equal access to primary education in the Tanguar Haor'.

Both qualitative and quantitative methods have been applied in this research. The Focus Group Discussion (FGD) and interview method (semi-structured questionnaire) have been incorporated here for inclusively assessing the existing scenario of primary education. A total of sixty (60) respondents were involved in this research. Data from important persons of different professions-Government officials, elected peoples' representatives, civil society members, and NGO activists have been collected using the Key Informant Interview (KII) method. No primary student was included in the interview on the ethical ground as they are not enough matured to give a rational opinion.

\section{Statement of the Research Problem}

'Education is one of the basic needs for human development and to escape from poverty' (Sivakumar \& Sarvalingam, 2010). An appropriately educated nation, which is modern in genius and intellect and forward-looking in thinking, can only put the country at the zenith of its development (National Education Policy, 2010). The need for educational access, and securely acquired knowledge and skill, is both a part of the definition of poverty and a means for its diminution (Ahmed, Ahmed, Khan, \& Ahmed, 2007). Basic or primary education is the foundation of building up a skilled nation and the first step to incorporate the entire populace within the education system (National Education Policy, 2010). This is the constitutional responsibility of the state to create equal opportunities in ensuring access of all sections of children to primary education irrespective of ethnicity, socio-economic conditions, physical or mental challenges, and geographical differences (National Education Policy, 2010). As primary education is the foundation of all education systems, the state of primary education should be studied first before exploring the existing education scenario of any area. Primary education in the rural and poor areas of the countryside of Bangladesh is severely affected than secondary and higher education due to environmental hazards and poverty (Trines, 2019). The Haor region is a backward place of the country in terms of most of the development indicators like education, socio-economic and communication (CEGIS, 2012b). As Tanguar Haor is an ecologically challenged haor area of Bangladesh (International Union for Conservation of Nature [IUCN], 2016), environmental hazards-induced 
problems adversely affect the primary education in the area. For instance, schools in vulnerable areas remain closed for an uncertain period during flash floods. Both teachers and students could not go to school at that time due to poor road connectivity. Consequently, it influences the percentage of attendance of school students (Deshwara, 2017). Besides, most of the people of this area are poor farmers, fishermen, and day labour. Many times, flash floods and other environmental calamities destroy the vast number of crops of this area. As crop cultivation and farming are the main sources of income, these sorts of threats are causes of poverty and severe grievances of these people (Firoz et al., 2010). Parents could not afford the cost of education for their children, and they intend to engage them in the income generated work or jobs instead. As a result, parents are compelled to withdraw their children from school which ultimately increased the dropout rate of primary students. Drop out is a core problem in ensuring quality primary education in Bangladesh (Zaman, 2014). In comparison to the primary education of other areas of Bangladesh, Haor areas in Sunamganj District are witnessing the highest dropout rate at the primary level when education specialists, officials of government and non-government institutions, and local people blamed the fragile road connectivity, poverty, and deficiency of better school infrastructure for this problem ("Highest dropout in primary education", 2014). Besides, after literature review, it has been found that NGOs, government departments, and academicians have done several worthy types of research on poverty and socio-economic problems of Tanguar Haor whereas no in-depth research was found on primary education of this area. Under these circumstances, it has been decided to conduct comprehensive research on equal access to primary education of Tanguar Haor.

\section{Literature Review}

Access to education is seen as the main basis in development strategies. The knowledge and skill that educational participation can and should confer on the next generation will contribute to poverty alleviation even though that this alone will be an essential but inadequate condition for advancement (Lewin, 2007). On the other hand, some of the realities and concerns like teachers' punctuality, students' attendance, facilities provided to teachers, socio-economic conditions of students' guardians, lack of school working calendar and proper schedule, inadequate space in classrooms, gender discrimination, seasonal problems and disability that surround access and exclusion of primary education in the rural 
areas of developing countries like Bangladesh (Sommers, 2011; Khan, Rana, \& Haque, 2014). Due to these functional flaws, 16 percent of working days are lost every year from primary school education in Bangladesh and the incidence of teacher absenteeism is as high as 15 percent (Khan et al., 2014). Such multifaceted challenges and constraints adversely affect the learning outcomes of school children in many low- and middle-income countries (L\&MICs) (Pritchett, 2013; Robinson, 2011; United Nations Educational, Scientific and Cultural Organization [UNESCO], 2015; Snilstveit et al. 2016). It is needless to say that equal access to and quality of primary education largely depends on overcoming these challenges (Haq, Ehsan, \& Jabbar, 2004).

This scenario of primary education is worse in the environmental conflict-prone area of Bangladesh. School children are the worst victim of the increasingly continual and harsh weather events, desertification, and flooding produced by climate change. Extreme disasters affect the children's schooling, the parents' ability to send their children to school, and the livelihoods of people of the disaster-prone area in Bangladesh (Reeve, 2015). In environmentally challenged and flood-prone areas, schools remain closed during floods and flash floods. The level of resilience of the primary education system is very low in such areas. This is because of poverty, livelihood dependent on natural resources, and scanty climate receptive curricula that at long last put the children's primary education at high risk (Reeve, 2015). For Haor areas of Bangladesh, some more specific reasons are responsible for inequalities in access to primary education. Stumbling blocks, e.g., geographical isolation, flash flood, poor communication system, periodic unemployment, economic privation, parental unawareness, inadequate number of schools, poorly regulated system produce discriminations in access to primary education and keep the children away from schooling in wetland areas of Bangladesh, and gradually marginalized the haor dwellers (Alam, 2018). These obstacles lead to the low-learning outcome of school children and eventually, dropout (United Nations International Children's Emergency Fund [UNICEF], 2018) that is considered a major problem in many developing countries like Bangladesh in providing equal access to quality primary education for all (Hunt, 2008).

Aforesaid literature that has been reviewed here explains the different reasons for not having equal access to primary education and not ensuring quality primary education for all. The literature related to the primary education of rural 
Bangladesh and the haor area has attributed some drawbacks like poor socioeconomic conditions of parents, dropout of students, parents' unconsciousness, climate change, and environmental hazards to the lack of equal access to and quality primary education of Bangladesh. Nevertheless, no literature was found which analyses how the environmental threats extremely influence the other factors that create hindrance to ensure equal access to primary education in the environmentally challenged area of Bangladesh like Tanguar Haor. This gap has been analysed in this article that how climate change-induced threats and environmental hazards act as core causes of deterring from ensuring equal access to and quality primary education in Tanguar Haor.

\section{Methodology of the Study}

This study has been conducted in the Tanguar Haor of Sunamganj District as this haor is an environmentally challenged and most vulnerable haor area of Bangladesh. Only government primary schools have purposively been selected to unfold the existing problems of primary education of study area due to time constraints and budget limitation. The research is an outcome of a joint effort of qualitative and quantitative approaches. The primary data used in this research have been collected through the survey, the Focus Group Discussion (FGD) and the Key Informant Interview (KII) method when secondary data from relevant books, publications, dissertations, journal articles, reports (government and nongovernment), newspapers, organizations related to climate change and environment and related websites. The interview method with a semi-structured questionnaire has been applied here because it allows depth to be achieved by providing the opportunity on the part of the interviewer to probe and expand the interviewee's responses (Rubin \& Rubin, 2005).

\section{Sampling-purposive}

The Tanguar Haor of Sunamganj District consists of four unions-Uttar Sreepur, Dakshin Sreepur, Uttar Bangshikunda and Dakshin Bangshikunda. Uttar Sreepur and Dakshin Sreepur lie in the Tahirpur Upazila whereas Uttar Bangshikunda and Dakshin Bangshikunda are under Dharmapasha Upazila. To examine the adverse effects of environmental hazards on primary education in Tanguar Haor, eight villages have purposively been selected from the abovementioned four unions as these localities are highly vulnerable to flash floods, climate change-induced 
threats, and other environmental hazards. The selected villages are Joypur and Mujrai from Uttar Sreepur; Lama Gaon, Ramshingopur and Patabuka from Dakshin Sreepur; Antorpur and Nababpur from Uttar Bangshikunda and Rongchi from Dakshin Bangshikunda. There are six government primary schools-Joypur Government Primary School (students from Joypur and Mujrai villages study in this school), Lama Gaon Government Primary School, Ramshingopur Government Primary School, Patabuka Government Primary School, Antorpur and Nababpur Government Primary School (students from Antorpur and Nababpur villages study in this school) and Rongchi Government Primary School which cover the primary education of aforesaid eight villages. The primary data have been collected from the said villages and primary schools through the survey, FGD, and KII (Key Informant Interview).

\section{Sample Size}

A total of sixty (60) respondents (48 in FGD and 12 in KII) purposively chosen from different professions were involved in this research. Focus Group Discussion (FGD) has been applied amongst the following individuals who have homogeneous backdrops or experiences to reconnoitre the sense of survey data. Data have also been collected from twelve key informants of different professions who have come up with insights on the attributes of problems of the haor community.

Table 1: Respondents in FGD and KII; researcher's dataset

\begin{tabular}{|c|c|c|}
\hline Numbers of FGD & $\begin{array}{l}\text { Profession } \\
\text { Participants }\end{array}$ & $\begin{array}{c}\text { Number of Participants } \\
\text { (Persons) }\end{array}$ \\
\hline FGD-1 & Male Primary Teacher & 8 \\
\hline FGD-2 & Female Primary Teacher & 6 \\
\hline FGD-3 & Guardians_-farmer & 8 \\
\hline FGD-4 & Guardians - fisherman & 8 \\
\hline FGD-5 & Guardians-job holder & 6 \\
\hline FGD-6 & Guardians - day labour & 6 \\
\hline FGD-7 & $\begin{array}{l}\text { Colleges students - three } \\
\text { boys and three girls }\end{array}$ & 6 \\
\hline
\end{tabular}




\begin{tabular}{lll}
\hline KII & $\begin{array}{l}\text { Government officials } \\
\text { (Upazila Nirbahi Officer }\end{array}$ & \\
and Upazila Education & \\
& Officer), elected peoples' \\
& representatives (Union & \\
& Parishad Chairman and \\
& members), civil society & \\
members, and NGO & \\
activist & $\mathbf{6 0}$ \\
\hline Total & Total Participants & \\
\hline
\end{tabular}

Methods and Techniques of data analysis

Collected data have been organized in different subcategories in line with research objectives and questions. The written scripts and the audio recordings collected from the respondents and the documents gathered from secondary sources have been transliterated sharply for the qualitative analysis. Since the sample size is small, MS-excel has been used to prepare tables, charts, and diagrams, and to analyse all quantitative data.

\section{Ethical Issues}

On the ethical ground, respondents were free to provide information. The interviewer did not exert any pressure to unveil information that respondents did not wish to disclose. They also had the opportunity to refuse any question which they felt uncomfortable answering. Therefore, the relationship with the respondents during data collection was "professional" but "comfortable". Besides, in the analysis and reporting, the identification of respondents (such as real names) is anonymous. In this study, no primary student was interviewed on the ethical ground as they were not skilled enough to give a rational opinion.

\section{Data Findings and Analysis}

The existing scenario of primary education in Tanguar Haor is not good enough compared to the primary education of other rural areas of the country. The majority of the respondents answered that environmental hazards due to climate change are the core cause of the disruption of the quality of primary education in this area. Environmental threats, consequently, generate various challenges that eventually create hindrance in making sure equal access to primary education for all in Tanguar Haor. 


\section{Flash Flood}

Flash flood is common in the Haor basin during the pre-monsoon (March-May) period. It is the main disaster in the haor area that engulfs the primary production sector (e.g., agriculture) and thus threatens the lives and livelihoods of the people, especially share-croppers and landless farmers (CEGIS, 2012a), that eventually create various adverse effects on the education of their children. Thirty-six (75\%) of the respondents think that flash flood is a phenomenon of climate change while the rest twelve interviewees $(25 \%)$ have not clear idea about the impact of climate change, but they agreed that flash flood is a major problem in their locality (Fig. 1).

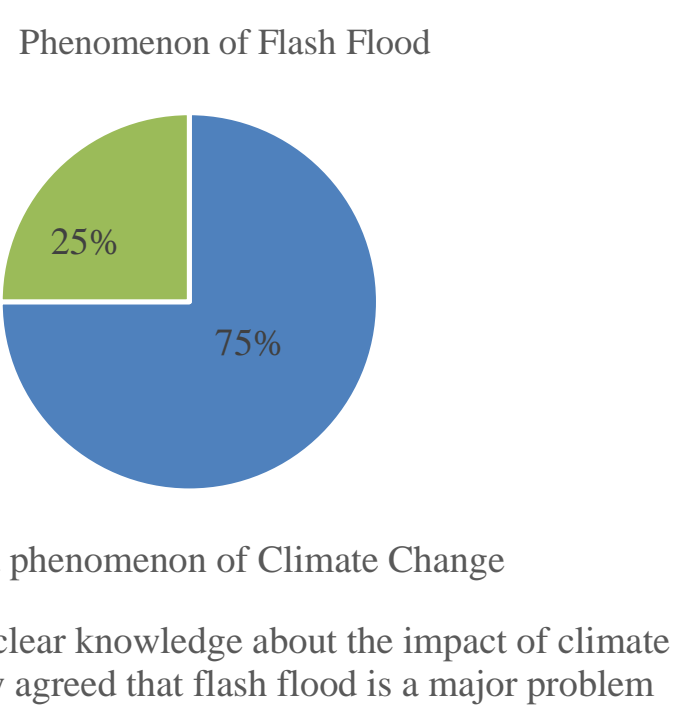

Figure 1: Whether flash flood is a phenomenon of Climate Change or not.

Flash flood undesirably influences the income sources of individuals in the haor area. During and after the flash flood time, most of the people of the haor area either migrate to other areas or switch their jobs to earn money. Twenty-six $(54.17 \%)$ of the participants opine that they have to migrate to other areas like Dhaka, Chattogram, Sylhet, and Feni, while eighteen (37.5\%) respondents think that they are compelled to switch their current jobs to manage livelihoods for their family (Fig. 2). 


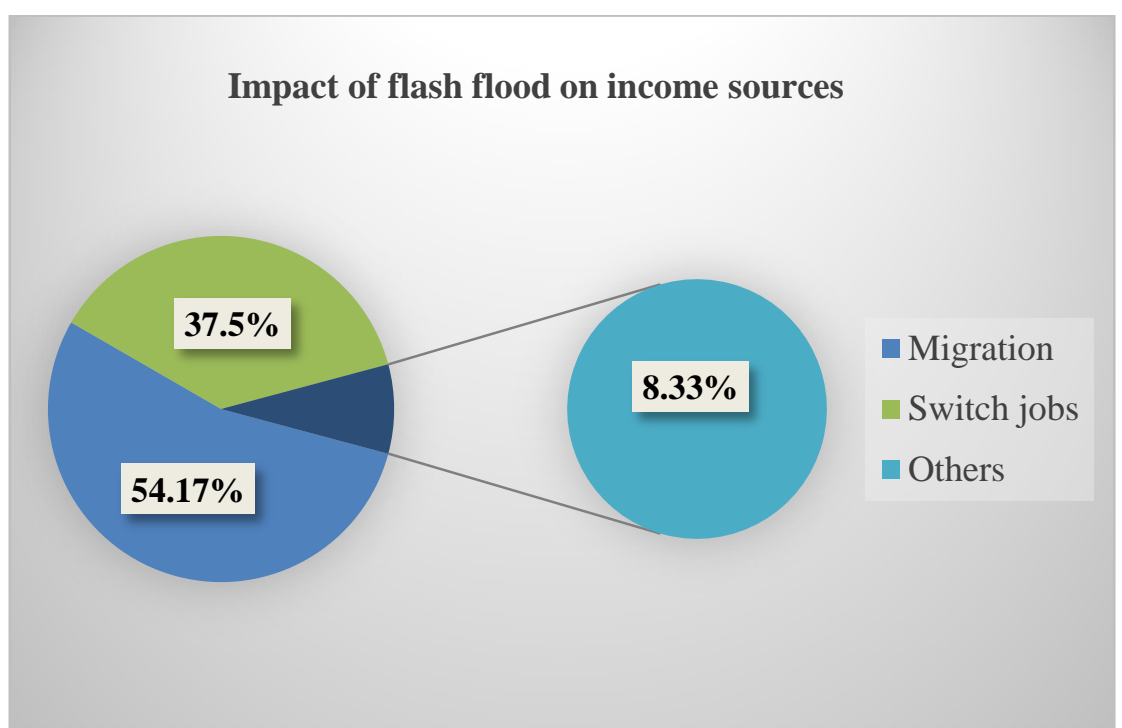

Figure 2: Flash flood-induced factors that affect income sources.

Due to flash floods, $89.58 \%$ of the respondents are directly affected by property loss, disease, and shortage of pure drinking water while $10.42 \%$ of respondents agree that flash floods affect them indirectly (Fig. 3). Besides this, seasonal floods, kalboishakhi jhar, and drought are frequent disasters in Tanguar Haor.

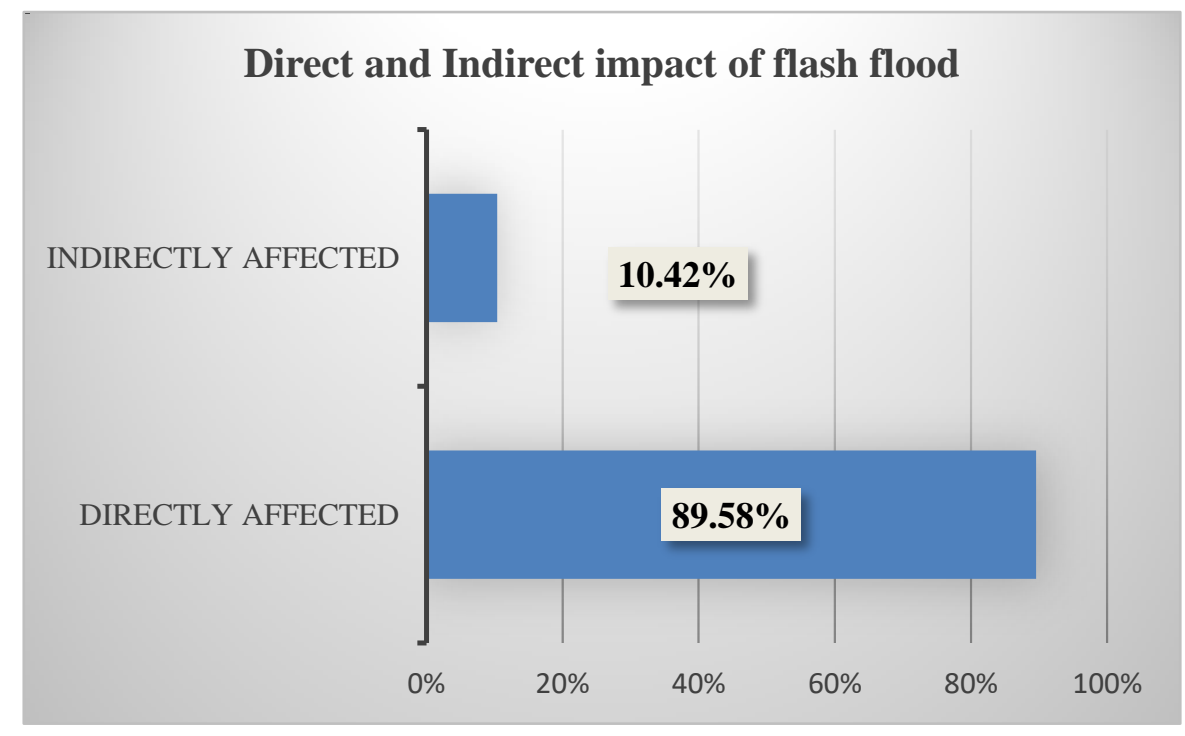

Figure 3: Opinion of respondents on the direct and indirect impact of flash floods. 
The most recent flash flood hit the Tanguar Haor in 2017. The Flash flood of 2017 started in late March affecting six districts (Sylhet, Moulvibazar, Sunamganj, Habiganj, Netrokona, and Kishoreganj) in the northeast region of Bangladesh. Sunamganj District has been affected most extensively. The flash flood of 2017 damaged 18,610 and 7,610 hectares of standing crops in the boro fields of Dharmapasha and Tahirpur Upazila respectively (Network for Information, Response and Preparedness Activities on Disaster [NIRAPAD], 2017). The Head Teacher of 2 No. Dharmapasha Govt. primary school said that in 2017, a flash flood hit earlier than usual, while Boro farmers were still waiting to harvest the crop. Sunamganj district administration data shows more than 300,000 families were affected in the district, but the government was only able to support 168,000 families by providing Vulnerable Group Feeding (VGF) support that consists of $30 \mathrm{kgs}$ of rice and Tk500 per month for one year (Siddique, 2017). This VGF support was not enough for maintaining a family of 5-7 members - told a farmer of Mujrai village, Uttar Sreepur Union, Tahirpur Upazila. On the other hand, as most of the relief goods have been distributed in areas that have roads in the Haor basin, remote areas have not received any relief yet. Flash flood adversely affects the regular attendance of primary students in their schools. As the Member of Ward No. 7, South Sreepur Union Parishad, Tahirpur said,

More than 90 percent of the land of this union sink underwater during floods. There are two villages of this union that are more vulnerable than other villages-Matidoyal and Kodomtoli. Children in this flood-hit area face severe problems in going to schools. As a result, they have remained absent from school during flash floods.

The then (2019) Upazila Education Officer of Dharmapasha said that natural environmental calamities create hindrance severely in ensuring equal access to and quality primary education. She added,

This flash flood affects the people in this region along with the student. Guardians afraid to send their children to school during the flood and the teacher's condition is the same here. They feel anxious in thinking that if the child goes to school during the flood an accident could happen. The poor students could not even manage a boat for going to and returning from school. It consequently reduces the regular attendance of primary students. 
A landless farmer, who is solely dependent on fishing and farming as his livelihood earning, of Joypur village of Tahirpur Upazila, told,

Water remains here for about six months which creates difficulty for the students to maintain regularity in the class. Thus, students cannot go to school during the flood due to not having a boat. That is why a boat is urgently needed here.

\section{Poor Road Connectivity}

Apart from the distance the difficulty to reach the school may be faced due to lack of smooth road connectivity. If the school can be reached by road most of the times of a normal year it is considered as easy to reach. If there are some obstacles like agricultural fields or small water body in between the school and the Upazila town it is considered moderately difficult, and if the way is underwater for major parts of the year or big water bodies or hilly areas in between it is considered as hard to reach (Nath \& Chowdhury, 2008). In this study, more than thirty-six respondents $(75 \%)$ think that it is hard to reach primary school while twelve persons $(25 \%)$ consider it as moderately difficult to reach (Fig. 4). But no one thinks that it is easy to reach primary school in their area. Because haor areas remain underwater for 4-7 months during the pre-monsoon and monsoon seasons.

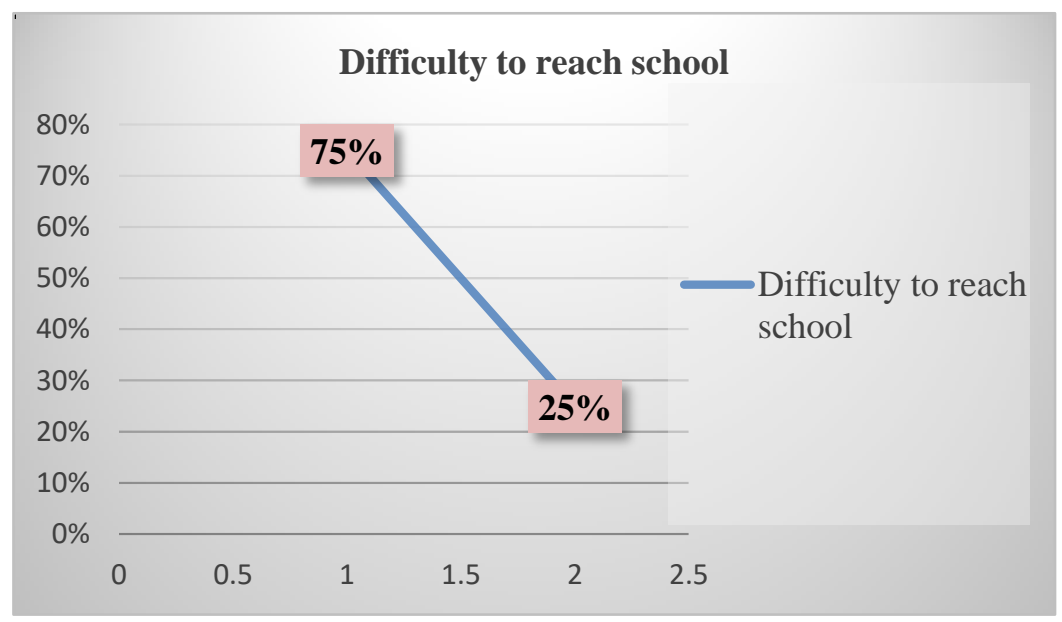

Figure 4: Difficulty of reaching primary schools in Tanguar Haor due to poor road connectivity. 
In this research, all respondents believe that poor road connectivity makes a hindrance towards ensuring equal access to quality primary education in Tanguar Haor. Forty $(83.33 \%)$ respondents agree that poor road connectivity has a direct effect when only eight $(16.67 \%)$ think that it has an indirect impact on primary education in Tanguar Hoar (Fig. 5).

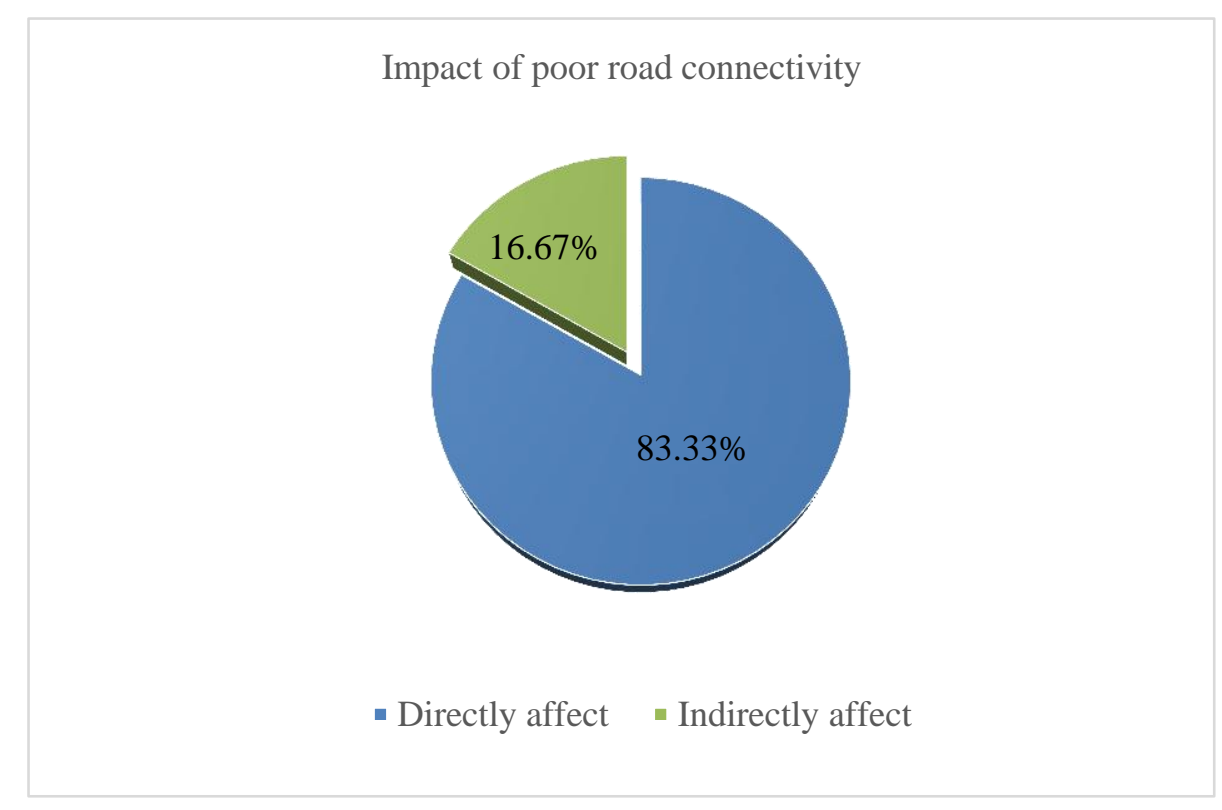

Figure 5: Impact of poor road connectivity on Primary Education.

Poor road connectivity, which is the result of frequent flash floods, seriously affects the primary education of Tanguar Haor. Thirty-one $(64.58 \%)$ of total respondents think that environmental hazards are responsible for the fragile communication system in Tanguar Haor when seventeen respondents (35.42\%) blame other reasons for the poor communication system (Fig. 6). 


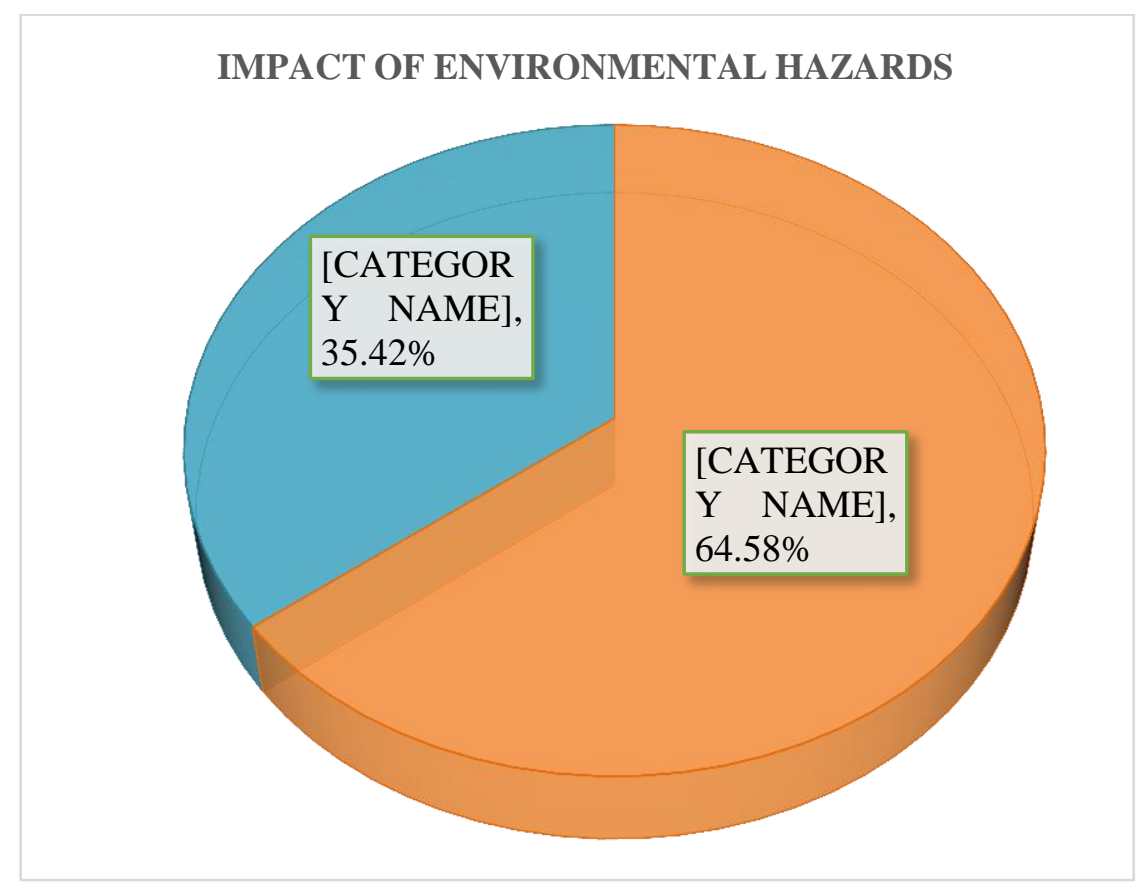

Figure 6: Severe impact of Environmental hazards on the communication system.

Primary students usually go to school on foot in the remote area of the haor region and they have to depend on a boat during the flood. If they do not manage any boat then the school is missed for that day, and that is why the rate of attendance is decreased in this period. Teachers of this area also suffer due to inadequate facilities of staying in their duty station. There are many primary schools in this Upazila which are almost $40-50 \mathrm{~km}$ away from Upazila town. The reality has been revealed in the words of the Head Teacher of Lama Gaon Government Primary School, Tahirpur, Sunamganj,

Education system of this area is being hampered due to poor road connectivity. Flash flood is one of the main causes of such a fragile communication system in this Upazila. Teachers at primary schools in this area have to go 5-6 km away to deliver a lecture as they could not stay in their duty station during the flood. Most of the time, they cannot even manage a boat for going to school. Schoolgoing children face severe difficulties due to such a communication problem.

The acting Head Teacher of Antorpur Nababpur Government Primary School blames the poor road connectivity as one of the major obstacles for achieving equal access to primary education in Tanguar Haor. She further said, 
The major problem here in ensuring equal access to and quality primary education for all is the bad communication system. A natural disaster is also an obstacle to providing quality education. It is very dangerous to come here during the rainy season. As it is risky for a teacher, it is more dangerous for students as well. Only five students remain in attendance among thirty students and so many students are not able to come here due to poor road connectivity.

A female farmer of Ramshingopur village (Tahirpur Upazila) who forcefully stops going to school for her children during harvesting time due to poverty, similarly, answered about the road the connectivity in the haor area. In her opinion,

Here road communication is not good and lots of students have to use the boat for going to school during the flash flood and heavy rain which is the reason not going to school.

A guardian (job holder) of South Bongshinkunda union of Dharmapasha Upazila says,

As this is the haor area, we have to face different problems to send our children to school due to the natural disaster. The communication system of this area is worse than in other areas. We need some boats to go to school during the flood, but poor people many times could not manage a boat. Our schools remain closed during heavy rain and flood.

A female union Parishad member of Uttar Sreepur, Tahirpur says that the rate of education is better than in previous times and children are willing to go to school here. But some obstacles like fragile communication systems and poverty that are the results of environmental hazards create hindrance to the eagerness of children.

\section{Poverty and Food Shortage}

Despite the availability of huge resources, the haor basin is identified as a high food insecure locality and 'hot-spots' of poverty in Bangladesh (Farid, 2017). People living in the villages of Tanguar Haor do not have access to many of the basic amenities of life like electricity, water, sanitation, school, and markets (Haque \& Kazal, 2008). The dream of continuing reading of children of poor families of this area shatters due to poverty. Many of the students have a strong will to go to school and continue their studies. As the then (2017) Tahirpur Upazila Parishad chairman said that they continue their studies working as day laborers in the paddy fields. He added that they have to read old and torn books from their classmates and friends as they cannot purchase new books (Deshwara, 2017). The inhabitants of Tanguar Haor are mostly poor farmers and fishermen 
and survive below the poverty line (Alam \& Hasan, 2010). Crops cultivation is the main source of income for the livelihoods of people in this area. Many farmers fishing when they get free time from harvesting boro crops. No alternative sources of income are available here for the people during the flood and other natural calamities. Consequently, farmers are compelled to migrate to Dhaka, Sylhet, and Chattogram for their livelihoods. The peculiar characteristics of the high seasonality of the haor-based economy force local people to remain out of work for about half of the year resulting in income-poverty (Kazal, Villinueve, Hossain, \& Das, 2010).

Most of the respondents said that poverty and food shortage is a serious obstacle towards getting access to primary education. Besides, they added that different environmental vulnerabilities are mainly responsible for their poor economic condition as farming and fishing are their main sources of livelihood. Thirty-six (75\%) of the total respondents blame poverty while the rest of the twelve $(25 \%)$ respondents think that there have other reasons like guardians' unconsciousness, poor communication system, etc. are responsible for not getting equal access to primary education in Tanguar Haor (Fig. 7).

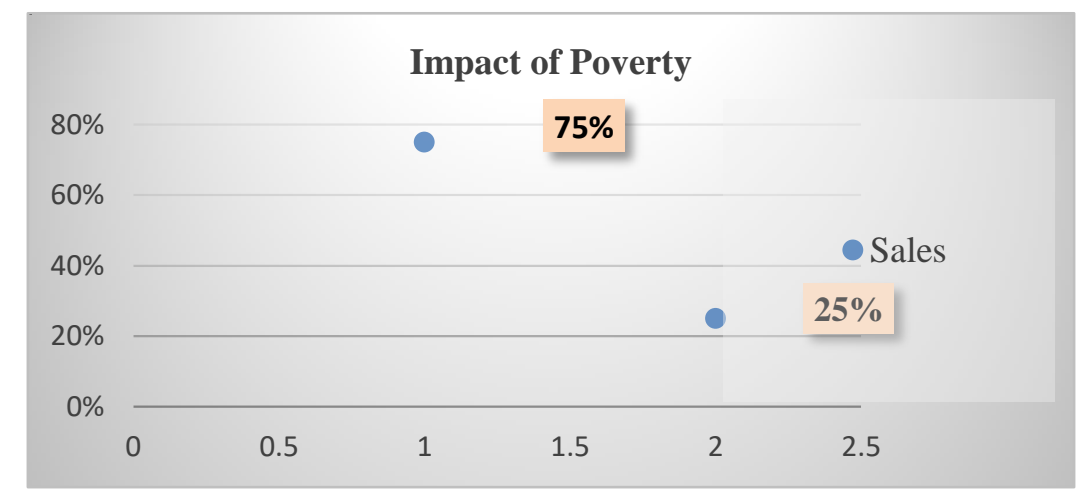

Figure 7: Impact of poverty on equal access to primary education.

The Union Parishad Chairman of South Sreepur, Tahirpur, said that they face various problems in getting equal access to primary education as this locality is a remote area of the Sunamganj district. He added that poverty is the main problem in this locality, and he also blames poverty as one of the prime causes of dropping out children from school. The Headteacher of Ramshingopur Government Primary School, Tahirpur, says, 
Poverty creates other problems like malnutrition and unwillingness of guardians that are the main obstacles to complete education here. Parents are so poor that they cannot even fulfil the basic demands of their children. We noticed that when their children do not get any scholarships or facilities from school, then they send them to madrasah to study almost free of cost. They demand that we will send our children to school if you provide us scholarship. So, I think that this is happened due to poverty.

A farmer of Lama Gao village, Dakshin Sreepur, Tahirpur, says,

Truly, the study of our children depends on our financial support. If we can provide money, then send the kids to school. Since we are poor farmers, we very often fail to send them to study.

Six students of Bangshikunda College that is located at Dakshin Bangshikunda, Dharmapasha, describe their experience to the researcher of how poverty makes a hindrance in getting equal access to education,

We have many friends and classmates in primary and secondary schools but only a few of us could enter college. Few of them were brilliant students but they could not continue their studies due to poverty. Most of the students here hail from poor farmer families, so they cannot afford the cost of education. Parents here think that it is better to engage their children in processing damaged crops during harvesting season. But it is true that in many times natural calamities and poverty force the guardians to do this.

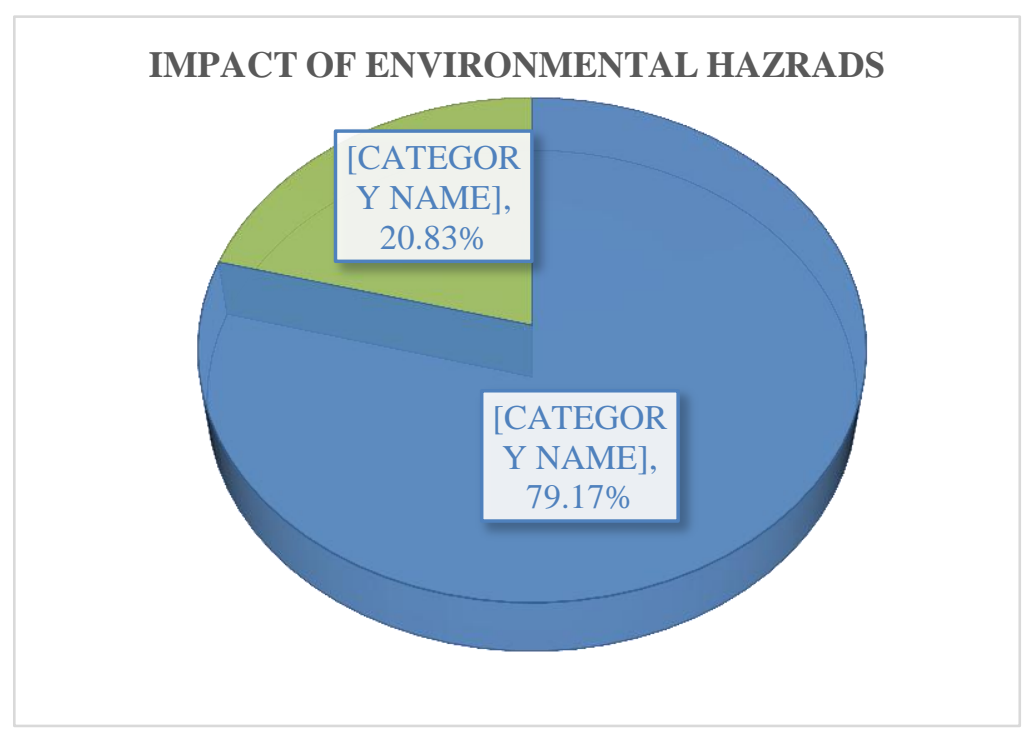

Figure 8: Impact of Environmental Hazards like flash floods on Poverty. 
Thirty-eight (79.17\%) of the total respondents opine that most of the people in this area are poor because frequently happened environmental hazards like flash floods directly affect the income sources and living status of the individuals. On the other hand, ten $(20.83 \%)$ respondents think that there are other reasons behind poverty like ancestral financial condition, lack of education, lack of a job, etc. (Fig. 8).

\section{High Dropout}

Compared to the increasing enrolment rate of students, the dropout rate is not decreased, rather the percentage of dropout students is alarming in Tahirpur and Dharmapasha Upazilas. The dropout rate is mainly high in the Tanguar Haor area due to children's attachment to farming and household activities. Poor socioeconomic conditions compel the parents to withdraw their children from school and to involve in income-generated activities. Most of the cases of dropout take place in Tahipur and Dharmapasha Upazila due to the direct and indirect effects of environmental threats. The Head Teacher of Patabuka Government Primary School said about the high dropout students at his school,

This area is highly vulnerable and remote; we do not get the touch of development. Parents of school-going children are extremely poor here, as a result, they send their children for crop harvesting and fishing to save and earn money. Parents think that children's activities with them to cultivate and harvest crops are more important than going to school as they get enough food grains from the crops for the whole year.

Table 2: Dropout students of six primary schools in five consecutive years (in percentage).

\begin{tabular}{|c|c|c|c|c|c|c|c|}
\hline \multirow[t]{2}{*}{ Name of School } & \multirow[t]{2}{*}{$\begin{array}{c}\text { Name of } \\
\text { Upazila and } \\
\text { District }\end{array}$} & \multicolumn{3}{|c|}{$\begin{array}{l}\text { Number of Enrolled } \\
\text { Students in Class } \\
\text { One (Five Years ago } \\
\text { of dropout year) }\end{array}$} & \multicolumn{3}{|c|}{$\begin{array}{l}\text { Dropout }(\%) \text { of three } \\
\text { consecutive years }\end{array}$} \\
\hline & & 2013 & 2014 & 2015 & 2017 & 2018 & 2019 \\
\hline $\begin{array}{lr}\text { Joypur } & \text { Govt. } \\
\text { Primary } & \text { School } \\
\text { (students } & \text { from } \\
\text { Joypur and Mujrai } \\
\text { villages } \\
\text { this study in } \\
\text { thool) }\end{array}$ & $\begin{array}{l}\text { Tahipur, } \\
\text { Sunamganj }\end{array}$ & 35 & 44 & 35 & 14 & 7 & 11 \\
\hline $\begin{array}{l}\text { Patabuka Govt. } \\
\text { Primary School }\end{array}$ & $\begin{array}{l}\text { Tahipur, } \\
\text { Sunamganj }\end{array}$ & 75 & 85 & 74 & 15 & 19 & 22 \\
\hline $\begin{array}{ll}\text { Ramshingopur } \\
\text { Govt. } \quad \text { Primary } \\
\text { School }\end{array}$ & $\begin{array}{l}\text { Tahipur, } \\
\text { Sunamganj }\end{array}$ & 30 & 32 & 29 & 10 & 6 & 3 \\
\hline
\end{tabular}




\begin{tabular}{lccccccc}
\hline $\begin{array}{l}\text { Lama Gaon Govt. } \\
\text { Primary School }\end{array}$ & $\begin{array}{c}\text { Tahipur, } \\
\text { Sunamganj }\end{array}$ & 60 & 55 & 43 & 2 & 4 & Nil \\
\hline $\begin{array}{l}\text { Antorpur } \\
\text { Nababpur Govt. } \\
\text { Primary School }\end{array}$ & $\begin{array}{c}\text { Dharmapasha, } \\
\text { Sunamganj }\end{array}$ & 54 & 70 & 52 & 7 & 7 & 12 \\
\hline $\begin{array}{l}\text { Rongchi Govt. } \\
\text { Primary School Dharmapasha, } \\
\text { Sunamganj }\end{array}$ & 32 & 65 & 43 & 25 & 14 & 23 \\
\hline
\end{tabular}

Source: Head Teachers of respective schools; researcher's dataset

Children in flood-hit areas of Sunamganj have remained absent from school for nearly a month during the flash and seasonal flood, it happens mostly because there are waters all around making it difficult for them to travel, and parents want them to help in saving crops gone underwater (Deshwara, 2017). The Head Teacher of Joypur Government Primary School, one of the worst affected schools of Tanguar Haor, presented the scenario of attendance that only 150 of 290 students would have to come to school by boat if they wanted to attend classes during floods (Deshwara, 2017).

Twenty-seven $(56.25 \%)$ of total respondents agree that environmental hazards are the main reason for the high dropout rate in primary education in Tanguar Haor while $37.50 \%$ and $6.25 \%$ of respondents blame respectively poverty and parents' unconsciousness for dropping out students from school (Fig. 9).

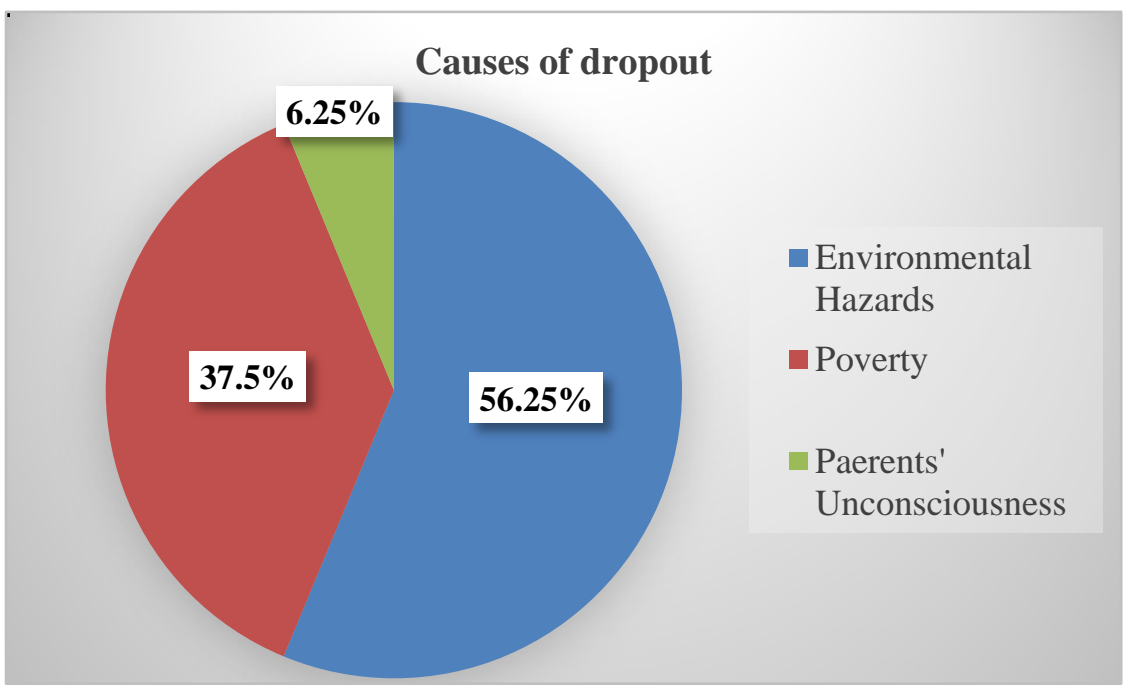

Figure 9: Causes of dropout that influence equal access to and quality primary education in Tanguar Haor 


\section{High Repetition}

A high number of students who enrolled in class one repeat in different classes at the same school before passing class five. The repetition percentage is more than the dropout ratio in purposively selected primary schools of Tanguar Haor. Respondents said that this is one of the major drawbacks in ensuring quality education in the haor area as the number of repeated students nearly double the number of dropout students. Teachers and guardians opine that repeated students eventually turned into dropout students. Because, students who repeat consecutively twice or thrice in the same class, finally cannot complete their primary education. They also added that natural calamities, poverty, guardians' unconsciousness, etc. are responsible for high repetition in the hoar area. The Head Teacher of Lama Gaon Government Primary School said,

During crops harvesting parents withdraw their children from school for helping out them or earning money; during the flood, students could not go to school due to lack of transport facilities because some family is extreme poor who even could not manage a boat for sending their children in school; poor children catch fish for selling in the local bazaar (market) to get some money; in the dry season, impoverished students receive 100-200 taka in a day in exchange of taking care of the cattle whole day of affluent farmers.

Table 3: Repeated Students in Six Primary Schools in five consecutive years

\begin{tabular}{|c|c|c|c|c|c|c|c|c|c|c|}
\hline \multirow[t]{2}{*}{$\begin{array}{l}\text { Name } \\
\text { School }\end{array}$} & \multirow[t]{2}{*}{$\begin{array}{c}\text { Name of } \\
\text { Upazila }\end{array}$} & \multicolumn{3}{|c|}{$\begin{array}{c}\text { Number of enrolled } \\
\text { students in class } \\
\text { one }\end{array}$} & \multicolumn{3}{|c|}{$\begin{array}{l}\text { Number of passed } \\
\text { students in class } \\
\text { five }\end{array}$} & \multicolumn{3}{|c|}{$\begin{array}{l}\text { Number of repeated } \\
\text { students } \\
\text { (assessment after } \\
\text { completing class } \\
\text { five) }\end{array}$} \\
\hline & & 2013 & 2014 & 2015 & 2017 & 2018 & 2019 & 2017 & 2018 & 2019 \\
\hline $\begin{array}{l}\text { Joypur } \\
\text { Govt. } \\
\text { Primary } \\
\text { School } \\
\text { (students } \\
\text { from Joypur } \\
\text { and Mujrai } \\
\text { villages } \\
\text { study in this } \\
\text { school) }\end{array}$ & $\begin{array}{l}\text { Tahipur, } \\
\text { Sunamganj }\end{array}$ & 35 & 44 & 35 & 20 & 32 & 25 & 10 & 09 & 06 \\
\hline
\end{tabular}

\begin{tabular}{|l|l|l|l|l|l|l|l|l|l|l|}
\hline Patabuka & Tahipur, & 75 & 85 & 74 & 17 & 17 & 11 & 27 & 35 & 26 \\
\hline
\end{tabular}




\begin{tabular}{|c|c|c|c|c|c|c|c|c|c|c|}
\hline $\begin{array}{l}\text { Govt. } \\
\text { Primary } \\
\text { School }\end{array}$ & Sunamganj & & & & & & & & & \\
\hline $\begin{array}{l}\text { Ramshingop } \\
\text { ur Govt. } \\
\text { Primary } \\
\text { School }\end{array}$ & $\begin{array}{l}\text { Tahipur, } \\
\text { Sunamganj }\end{array}$ & 30 & 32 & 29 & 12 & 14 & 18 & 10 & 12 & 08 \\
\hline $\begin{array}{l}\text { Lama Gaon } \\
\text { Govt. } \\
\text { Primary } \\
\text { School }\end{array}$ & $\begin{array}{l}\text { Tahipur, } \\
\text { Sunamganj }\end{array}$ & 60 & 55 & 43 & 17 & 13 & 15 & 42 & 37 & 25 \\
\hline $\begin{array}{l}\text { Antorpur } \\
\text { and } \\
\text { Nababpur } \\
\text { Govt. } \\
\text { Primary } \\
\text { School }\end{array}$ & $\begin{array}{c}\text { Dharmapas } \\
\text { ha, } \\
\text { Sunamganj }\end{array}$ & 54 & 70 & 52 & 33 & 35 & 25 & 12 & 20 & 15 \\
\hline $\begin{array}{l}\text { Rongchi } \\
\text { Govt. } \\
\text { Primary } \\
\text { School }\end{array}$ & $\begin{array}{c}\text { Dharmapas } \\
\text { ha, } \\
\text { Sunamganj }\end{array}$ & 32 & 65 & 43 & 06 & 18 & 12 & 18 & 33 & 21 \\
\hline
\end{tabular}

Sources: Head Teachers of respective schools; researcher's dataset.

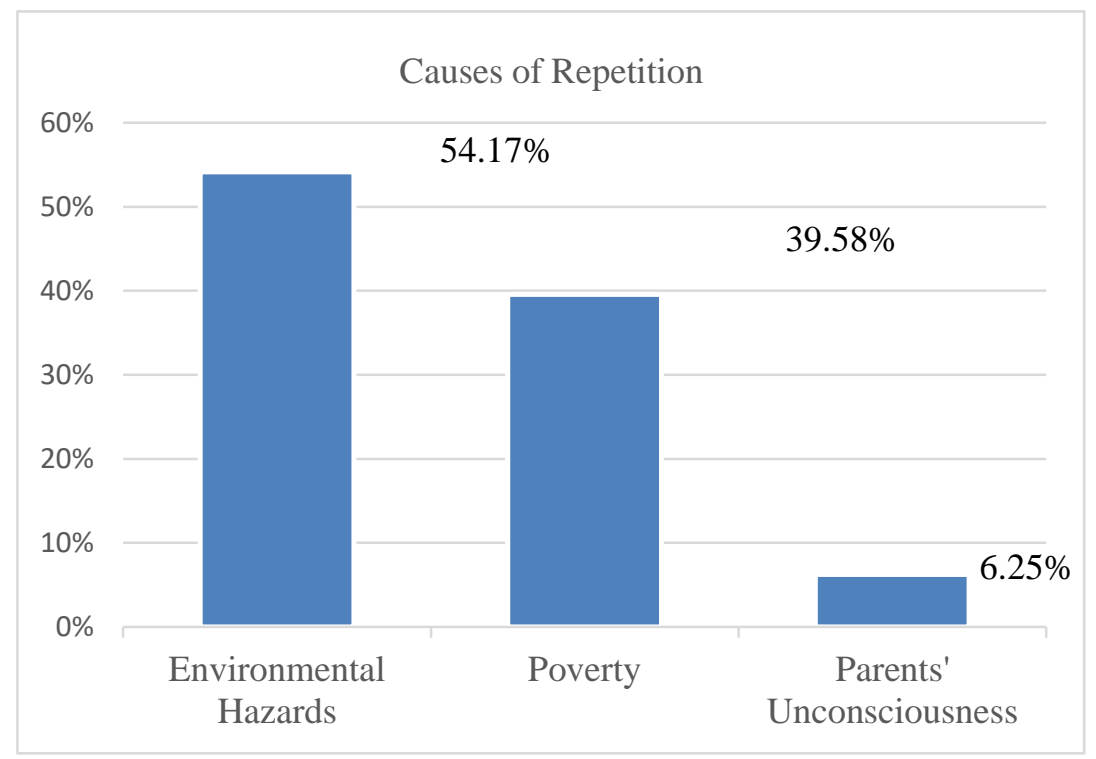

Figure 10: Factors of high repetition that affect primary education in Tanguar Haor. 
Twenty-six (54.17\%) of total respondents agree that environmental hazards are the main reason for the high repetition rate in primary education in Tanguar Haor when $39.58 \%$ and $6.25 \%$ of respondents blame respectively poverty and parents' unconsciousness for repetition of students in the same class for more than one year (Fig. 10).

Inadequate number of teachers and fragile infrastructure of educational institutions

Students of both primary and secondary education in Haor areas face difficulties in receiving quality education due to the inadequate number of teachers. The average ratio of students and approved posts of teachers is 41:1 in the study area which is very nominal than the number of teachers in other areas of the country. However, the ratio of students and available and active teachers is only 70:1 that is highly alarming for ensuring equal access to and quality primary education in Tanguar Hoar.

Table 4: Number of Teachers in selected primary schools as per received data in February 2020 from the Head Teachers of respective schools and Upazila Education Officers

\begin{tabular}{|c|c|c|c|c|c|}
\hline $\begin{array}{c}\text { Name of } \\
\text { School }\end{array}$ & $\begin{array}{c}\text { Name of } \\
\text { Upazila and } \\
\text { District }\end{array}$ & $\begin{array}{l}\text { Number } \\
\text { of Total } \\
\text { Students }\end{array}$ & $\begin{array}{c}\text { Number of } \\
\text { Approved } \\
\text { posts of } \\
\text { Teachers } \\
\end{array}$ & $\begin{array}{l}\text { Number of } \\
\text { Recruited/ } \\
\text { Active } \\
\text { Teachers } \\
\end{array}$ & $\begin{array}{c}\text { Number of } \\
\text { Vacant } \\
\text { Posts }\end{array}$ \\
\hline $\begin{array}{l}\text { Joypur Govt. } \\
\text { Primary } \\
\text { School } \\
\text { (students from } \\
\text { Joypur and } \\
\text { Mujrai villages } \\
\text { study in this } \\
\text { school) }\end{array}$ & $\begin{array}{c}\text { Tahipur } \\
\text { Sunamganj }\end{array}$ & 238 & 07 & 03 & 04 \\
\hline $\begin{array}{c}\text { Patabuka Govt. } \\
\text { Primary } \\
\text { School } \\
\end{array}$ & $\begin{array}{c}\text { Tahipur } \\
\text { Sunamganj }\end{array}$ & 316 & 05 & 04 & 01 \\
\hline $\begin{array}{c}\text { Ramshingopur } \\
\text { Govt. Primary } \\
\text { School } \\
\end{array}$ & $\begin{array}{c}\text { Tahipur } \\
\text { Sunamganj }\end{array}$ & 187 & 06 & 03 & 03 \\
\hline $\begin{array}{l}\text { Lama Gaon } \\
\text { Govt. Primary } \\
\text { School }\end{array}$ & $\begin{array}{c}\text { Tahipur } \\
\text { Sunamganj }\end{array}$ & 206 & 06 & 04 & 02 \\
\hline
\end{tabular}




\begin{tabular}{|c|c|c|c|c|c|}
\hline $\begin{array}{c}\text { Antorpur } \\
\text { Nababpur } \\
\text { Govt. Primary } \\
\text { School }\end{array}$ & $\begin{array}{c}\text { Dharmapasha } \\
\text { Sunamganj }\end{array}$ & 231 & 05 & 03 & 02 \\
\hline $\begin{array}{c}\text { Rongchi Govt. } \\
\text { Primary } \\
\text { School }\end{array}$ & $\begin{array}{c}\text { Dharmapasha } \\
\text { Sunamganj }\end{array}$ & 220 & 05 & 03 & 02 \\
\hline
\end{tabular}

All respondents agree that insufficient teachers either directly or indirectly affect equal access to primary education in Tanguar Hoar. Forty-one $(85.42 \%)$ respondents think that government should recruit more teachers following the number of students at respective school while only seven (14.58\%) respondents opine that the existing teachers should be more responsible and committed to their professions. (Fig. 11).

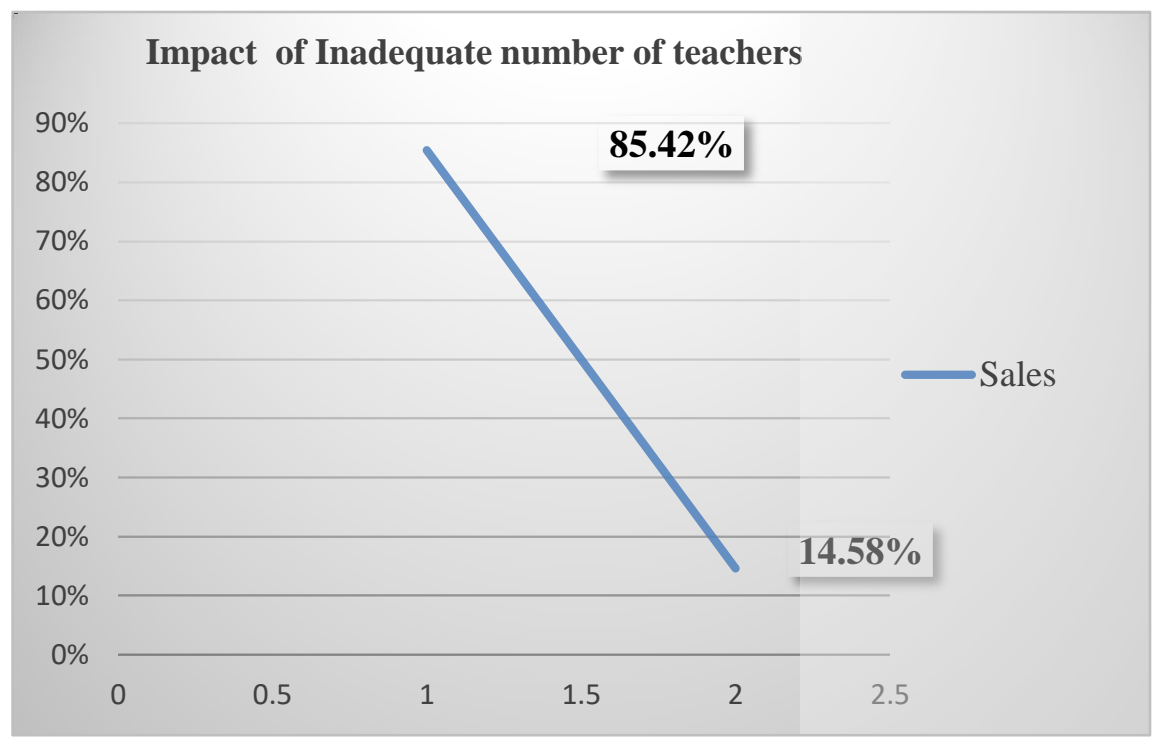

Figure 11: Impact of the inadequate number of teachers on primary education in Tanguar Haor.

A good number of teachers at primary schools in the remote area of Tanguar Haor live in urban areas instead of living adjacent to the schools due to infrastructural disadvantages and communication vulnerabilities. Thus, absenteeism and late arrival in and early departure from school are considerably higher in the Haor areas that eventually affects the contact hour of the learners (Raju, 2013). At the same time, Upazila Education Officials of Tahirpur and Dharmapasha Upazila are not willing to visit schools regularly due to 
communication barriers and are less proactive in addressing the key issues of school operation in terms of ensuring access and quality (Raju, 2013). The then (2019) Upazila Education Officer of Dharmapasha shared the difficulties of a female primary teacher of her Upazila to the researcher. She said,

There is a teacher, whose name is Popi Rani, and she is a daughter of freedom fighter, is employed in a school of this Upazila. We have seen that she has been working in that school since 2012. But we did not provide her accommodation from the Upazila Education Office end for leading a standard life. Consequently, she has been compelled to manage a house by herself to live but she has to pay a lot as house rent. She said to me by crying that I had been living here for almost seven years....finally she has to move to a different place when she became a mother because she could not survive in such a remote area. Nobody wants to work in the haor area due to different environmental calamities induced difficulties. There are many vacancies in the schools of haor are but no appointment.

Twenty-six (54.17\%) respondents said that the existing infrastructural facilities for primary teachers and students are extremely limited. Eighteen (37.50\%) respondents agree that the physical conditions of primary educational institutions are average, at the same time, they also think that the respective authority should improve the infrastructural facilities as early as possible when only four $(8.33 \%)$ of them believe that the existing conditions are good (Fig. 12).

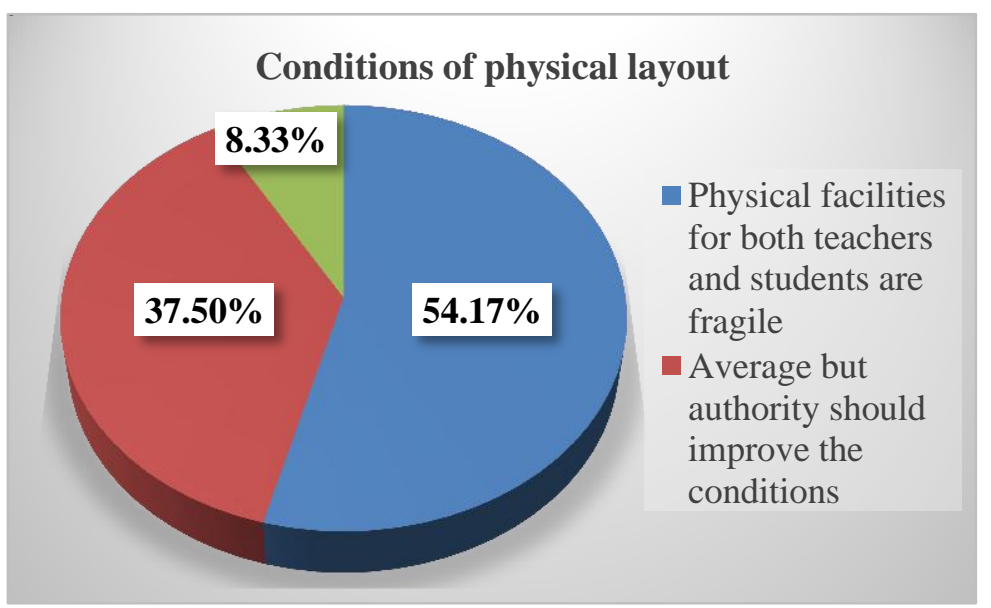

Figure 12: Conditions of the physical layout of educational institutions in Tanguar Haor. 


\section{Recommendations}

To overcome the existing problems in the way to ensure equal access to primary education in Tanguar Haor some recommendations can be prioritized. For example, if government provide VGF card and other facilities to poor families and increase the existing amount of student scholarships and ensure school feeding, the parents will not be forced to withdraw their children from school due to poverty. Besides, it is imperative to create alternative sources of income, introduce alternative cropping practices such as early variety and provide training on techniques, and reduce the extreme dependency on natural resources to improve the financial solvency of the parents. Furthermore, road connectivity should be developed and at least one boat for each poor family should be given to keep the students regular in the classroom. Potable water, basic health care, and hygienic toilets should be ensured to keep the children healthy. The dropout rate can be reduced if teachers create awareness among the guardians by doing regular home visits. In this connection, sufficient teachers should be recruited following the number of students in each primary school (at least six teachers including the headteacher).

\section{Conclusion}

Tanguar Haor, an extremely remote area in the haor basin of Bangladesh, is highly vulnerable to various natural and environmental disasters. The vast extent of water bodies and the prolonged duration of submergence has made the area environmentally challenged, remote, and difficult for human settlement. The extreme remoteness, isolation, and difficulty for livelihood have adversely influenced the equal access to primary education in Tanguar Haor.

Findings of the research show that the state of primary education of Tanguar Haor is not good in comparison to the condition of primary education in other areas of the country. There are many identified problems like a flash flood, poverty, food shortage, fragile communication system and inadequate infrastructure of educational institutions due to wave related erosion, inadequate number of teachers, lack of proper health facilities, scarcity of pure drinking water, lack of proper sanitation, etc. which are responsible for making the working system of primary education dysfunctional in Haor area. More importantly, the research findings indicate that climate change and environmental vulnerabilities are primarily responsible for producing these drawbacks that 
create hindrances towards getting equal access to primary education. Migration, due to the dearth of works particularly in the monsoon season, and poverty accelerate the drawbacks of education in this area. Crop damage due to climate change-induced disasters like early monsoon flash floods is considered the driving force for vulnerability and poverty of the area (Firoz et al., 2010).

However, it is inevitable to find out the ways for sorting out the existing drawbacks towards ensuring equal access to primary education in Tanguar Haor. Initiatives from different sectors like government, NGOs, and the local community are essential to overcome the problems caused by natural disasters and environmental hazards. Some important issues have been highlighted as a solution in the recommendation section of this study to improve the status of and ensure equal access to primary education for all. The outcome of this research will be of great use to the academics, professionals, and particularly to the policymakers to formulate long-term policies and strategies in ensuring equal access to primary education in environmentally challenged areas of Bangladesh.

\section{Declaration of Interest}

This article is written from a research project that was funded by the Bangladesh Open University.

\section{References}

Ahmed, M., Ahmed, K. S., Khan, N. I. \& Ahmed, R. (2007). Access to Education in Bangladesh: Country Analytical Review of Primary and Secondary Education. Institute of Educational Development, BRAC University, Dhaka. Retrieved from https://www.academia.edu/ 2563048/Access_to_Education_in_Bangladesh_Country_analytic_review_of_primary_and_se condary_education (Accessed on October 11, 2019).

Alam, M. B. (2018). Inequalities in access to primary education: an investigation on "haor" (wetland) areas in Bangladesh. World Voices Nexus: The WCCES Chronicle, 2(3).

Alam, M. K., \& Hasan, M. R. (2010). Protection Works Against Wave Attacks in the Haor Areas of Bangladesh: Analysis of Sustainability. Journal of Construction in Developing Countries, $15(2), 69-85$.

Highest dropout in primary education in Haor areas. (2014, February 15). The Daily Prothom Alo. Retrieved from https://en.prothomalo.com/bangladesh/Highest-dropout-in-primary-educationin-Haor-areas (Accessed on September 28, 2019).

Centre for Environmental and Geographic Information Services (CEGIS). (2012a). Master Plan of the Haor Area. Bangladesh Haor and Wetland Development Board, Ministry of Water Resources, Government of the People's Republic of Bangladesh, 1, 10-43. 
Centre for Environmental and Geographic Information Services (CEGIS), (2012b). Master Plan of the Haor Area. Bangladesh Haor and Wetland Development Board, Ministry of Water Resources, Government of the People's Republic of Bangladesh, 2, 1-35.

Deshwara, M. (2017, May 01). No school for hoar kids for nearly a month. The Daily Star. Retrieved from https://www.thedailystar.net/frontpage/no-school-haor-kids-over-month1399045 (Accessed on October 11, 2019).

Deshwara, M. (2017, May 07). Haor flood shatters dream of education. The Daily Star. Retrieved from https://www.thedailystar.net/country/haor-flood-shatters-dream-education-1401655 (Accessed on October 11, 2019).

Farid, S. (2017, November 10). In search of a development model for haor dwellers. The Daily Observer. Retrieved from https://www.observerbd.com/details.php?id=105109 (Accessed on June 09, 2019).

Firoz, R., Adrika, A., Wahed, A., Hasiba, Z., Sinha, K., Mahbub, M. \& Khan, M. A. (2010). Disaster Risk Reduction (DRR) on Tanguar Haor. Dhaka: IUCN Bangladesh Country Office.

Haque, A. K. E., \& Kazal, M. H. (2008). Rich Resources, Poor People: The Paradox of Living in Tanguar Haor. Retrieved from http://acdonline.org/wp-content/uploads/2014/12/dr _enam_s_socio_economic_report_on_th.pdf (Accessed on July 15, 2019).

Haq, M. N., Ehsan, A., \& Jabbar, A., (2004). Assessing Quality of Primary Education in Bangladesh. Bangladesh Education Journal, 03(1), 13-26.

Hunt, F. (2008). Dropping out from school: A cross-country review of literature. Retrieved from the Centre for International Education, University of Sussex, UK website: http://www.createrpc.org/pdf_documents/PTA16.pdf

International Union for Conservation of Nature (IUCN). (2016). Tanguar Haor: A Decade-long Conservation Journey. Dhaka: IUCN, Bangladesh Country Office.

Kazal, M. M. H., Villinueve, C., Hossain, M. Z., \& Das, T. K. (2010). Food Security Strategies of the People Living in Haor Areas: Status and Prospects. Retrieved from http://fpmu.gov.bd/agridrupal/sites/default/files/Final_Technical_Report_Kazal.pdf (Accessed on May 17, 2019).

Khan, M. N. U., Rana, E. A. \& Haque, M. R. (2014). Reforming the Education System in Bangladesh: Reckoning a knowledge-based Society. World Journal of Education, 04(4), 1-11.

Lewin, M. K. (2007). Improving access, equity and transitions in education: Creating a research agenda. Retrieved from http://www.create-rpc.org/pdf_documents/PTA1.pdf (Accessed on May 17, 2019).

Ministry of Environment and Forests (MoEF). (2009). Bangladesh Climate Change Strategy and Action Plan 2009. Dhaka: Ministry of Environment and Forests, Government of the People's Republic of Bangladesh.

Nath, R. S. \& Chowdhury, M. R. A. (2008). State of Primary Education in Bangladesh: Progress Made, Challenges Remained. Dhaka: Campaign for Popular Education (CAMPE) Bangladesh.

National Education Policy (2010). Ministry of Education. Dhaka: Ministry of Education, Government of the People's Republic of Bangladesh.

Network for Information, Response and Preparedness Activities on Disaster (NIRAPAD). (2017). Flash Flood Situation, April 19, 2017. Retrieved from https://reliefweb.int/sites/ reliefweb.int/files/resources/Flash_Flood\%2C\%20Updated\%20\%28April\%2019\%29\%2C\%20 2017.pdf (Accessed on October 13, 2019). 
Pritchett, L (2013). The Rebirth of Education: Schooling Ain't Learning. USA: Washington, D.C., Centre for Global Development.

Raju, M. N. A. (2013, August 26). Haor Education: Should distance be the barrier? The Daily Star. Retrieved from https://www.thedailystar.net/news/haor-education-should-distance-be-thebarrier (Accessed on September 18, 2019).

Reeve, S. (2015). Children and the Changing Climate: Taking action to save lives. UK: UNICEF.

Robinson, J. P. (2011). A global compact on learning: Taking action on education in developing countries. Centre for Universal Education. USA: Washington, D.C., Brookings Institution.

Rubin, J. H. \& Rubin, S. I. (2005). Qualitative Interviewing: The Art of Hearing Data. Los Angeles, USA: Sage Publications.

Siddique, A. (2017, July 31). NGOs help bridge aid gap in Haor basin. Dhaka Tribune. Retrieved from https://www.dhakatribune.com/bangladesh/nation/2017/07/30/ngos-help-bridge-aid-gaphaor-basin (Accessed on January 05, 2020).

Sivakumar, M., \& Sarvalingam, A. (2010). Human deprivation index: A measure of multidimensional poverty. Retrieved from the website of Munich Personal RePEc Archive: https://mpra.ub.uni-muenchen.de/22337/1/ (Accessed on October 11, 2019).

Snilstveit, B., Stevenson, J., Menon, R., Phillips, D., Gallagher, E., Geleen, M., Jobse, H., Schmidt, T. \& Jimenez, E. (2016). The impact of education programmes on learning and school participation in low- and middle-income countries. Systematic Review Summary 7. Retrieved from the website of International Initiative for Impact Evaluation (3ie): https://core.ac.uk/download/pdf/143615193.pdf (Accessed on October 19, 2019).

Sommers, C. (2011). Primary education in rural Bangladesh: Degrees of access, choice, and participation of the poorest. Retrieved from https://www.academia.edu/35118599/ Primary_education_in_rural_Bangladesh_Degrees_of_access_choice_and_participation_of_th e_poorest (Accessed on May 19, 2019).

Trines, S. (2019). Education in Bangladesh. Retrieved from https://wenr.wes.org/2019/08/ education-in-bangladesh (Accessed on November 28, 2020).

United Nations Educational, Scientific and Cultural Organization (UNESCO). (2015). Pricing the right to education: The cost of reaching new targets by 2030. Retrieved from https://unesdoc.unesco. org /ark:/ 48223/pf0000232197 (Accessed on June 26, 2019).

United Nations International Children's Emergency Fund (UNICEF). (2018). Quality, continuity for primary education. Retrieved from https://www.unicef.org/bangladesh/en/more-opportunitiesearly-learning/quality-continuity-primary-education (Accessed on August 13, 2019).

Zaman, M. M. (2014). Dropout at Primary and Secondary Level: A Challenge to Ensure Rights to Education for the Government of Bangladesh. Dhaka: Institute of Governance Studies, BRAC University. 